\title{
KARAKTERISASI RESERVOAR PADA LITOLOGI KARBONAT MENGGUNAKAN ANALISA INVERSI SIMULTAN DI LAPANGAN “MAF”
}

\author{
M. Afif Afianto, Wien Lestari, Firman Syaifuddin, Farid Dasa Marianto \\ Jurusan Teknik Geofisika, FTSP Instittut Teknologi Sepuluh Nopember \\ e-mail: afifafian@gmail.com
}

\begin{abstract}
Abstrak. Dalam dunia interpretasi geofisika, metode inversi masih menjadi metode efektif untuk mengetahui karakterisasi dari reservoar yang diteliti. Dari berbagai macam metode inversi, dikenal salah satunya adalah Inversi Acoustic Impedance (Al), yang telah dikenal dan digunakan untuk karakterisasi reservoar, baik dalam membedakan litologi maupun fluida. Namun, keterbatasan dari inversi Al adalah ketika membedakan litologi maupun fluida pada tipe batuan yang kompleks, yaitu karbonat. Karbonat memiliki karakteristik yang sulit untuk diprediksi dimana sering kali dijumpai memiliki nilai Impedansi dengan ambiguitas tinggi. Inversi Simultan menggunakan data seismik berupa angle yang terbagi kedalam near, mid dan far angle. Kemudian dilakukan inversi secara bersamaan menggunakan data angle gather dan wavelet hasil estimasi dari tiap range angle stack. Hasil yang didapatkan dari inversi ini adalah parameter Impedansi $\mathrm{P}$, Impedansi S, Densitas dan rasio Vp/Vs, yang didapatkan melalui data gelombang $\mathrm{P}$ dan gelombang $\mathrm{S}$. Pada penelitian ini dilakukan karakterisasi reservoar dengan menggunakan inversi simultan pada litologi karbonat di Formasi Ngimbang menggunakan dua sumur, AF2 dan AF3. Berdasarkan hasil yang diperoleh dari penelitian ini, diketahui bahwa zona target memiliki nilai Impedansi P antara $33208-43341$ (ft/s)*(gr/cc), Impedansi S antara $16088-25790$ (ft/s)*(gr/cc), dengan persebarannya berada pada barat laut dari sumur AF2.
\end{abstract}

Kata Kunci: impedansi; impedansi S; rasio Vp/Vs; karbonat

Abstract. In the Geophyisics Interpretation field, Inversion Method was still become the effective method in order to determine reservoir characterization of the reservoir that were observed. There were various methods of inversion, one of them was known Acoustic Impedance (Al) Inversion, which used for reservoir characterization, both in distinguishing lithology and fluids. However, there was a limitation of Al Inversion in distinguishing lithology and fluid for the complex formation, such as carbonate. Carbonate had the characteristics that were difficult to predict which were often found to had an ambiguity value of impedance. Simultaneous Inversion, using seismic data in the form of angle, that were divided into near, middle and far angle stack. Then the inversion was performed simultaneously using the angle gather data using two wells, AF1 and AF2, with estimation wavelet from each angle stack range. The Simultaneous Inversion result which were obtained from the $P$-wave and $S$-wave were $P$ Impedance, $S$ Impedance, Density and the Vp/Vs ratio. Based on the result that were obtained, the target zone had the value of $P$ Impedance between 33208 - 43341 (ft/s)*(gr/cc), S Impedance 16088 - $25790(\mathrm{ft} / \mathrm{s})^{*}(\mathrm{gr} / \mathrm{cc})$, and the oriented distribution was at North-West direction from Well AF2.

Keywords: P-impedance; S-impedance; Vp/Vs ratio; carbonate

\section{PENDAHULUAN}

Sumber daya energi minyak dan gas masih menjadi pemegang peran penting untuk ketahanan energi di dunia. Eksplorasi terus dilakukan untuk memenuhi kebutuhan energi yang semakin bertambah.

Sejalan dengan kebutuhannya yang semakin bertambah, teknologi dalam eksplorasi sumber daya minyak dan gas pun terus dikembangkan. Hal tersebut termasuk juga dalam metode yang dipakai di dalamnya, salah satunya yaitu di bidang geofisika. Bidang geofisika memiliki cakupan yang sangat luas dalam hal eksplorasi, salah satunya yaitu interpretasi seismik. Pengembanganpengembangan yang bertujuan untuk mendapatkan hasil yang lebih optimal dan akurat, seperti struktur bawah permukaan serta karakteristik reservoarnya terus dikembangkan di dalam dunia interpretasi geofisika, di antaranya adalah dengan Metode Inversi.

Metode Inversi bertujuan untuk mengetahui kondisi bawah permukaan berdasarkan model yang 
dibuat dengan data sumur dan seismik, sampai mendapatkan gambaran bawah permukaan yang paling baik. Salah satu Metode Inversi yang cukup terkenal dan sering digunakan dalam interpretasi adalah Inversi Simultan (Simultaneous Inversion). Metode ini bekerja dengan memanfaatkan data seismik berupa pre-stack gather, dengan fungsi jarak menggunakan angle, sehingga harus dilakukan proses precondition data terlebih dahulu. Model yang dibuat berupa Impedansi P, Impedansi $S$ dan Densitas. Perbedaan Inversi Simultan terletak pada kemampuannya dalam membuat volume parameter - parameter seperti Impedansi $P$, rasio Vp/Vs, Lambda - Rho \& Mu - Rho, hingga Poisson Ratio.

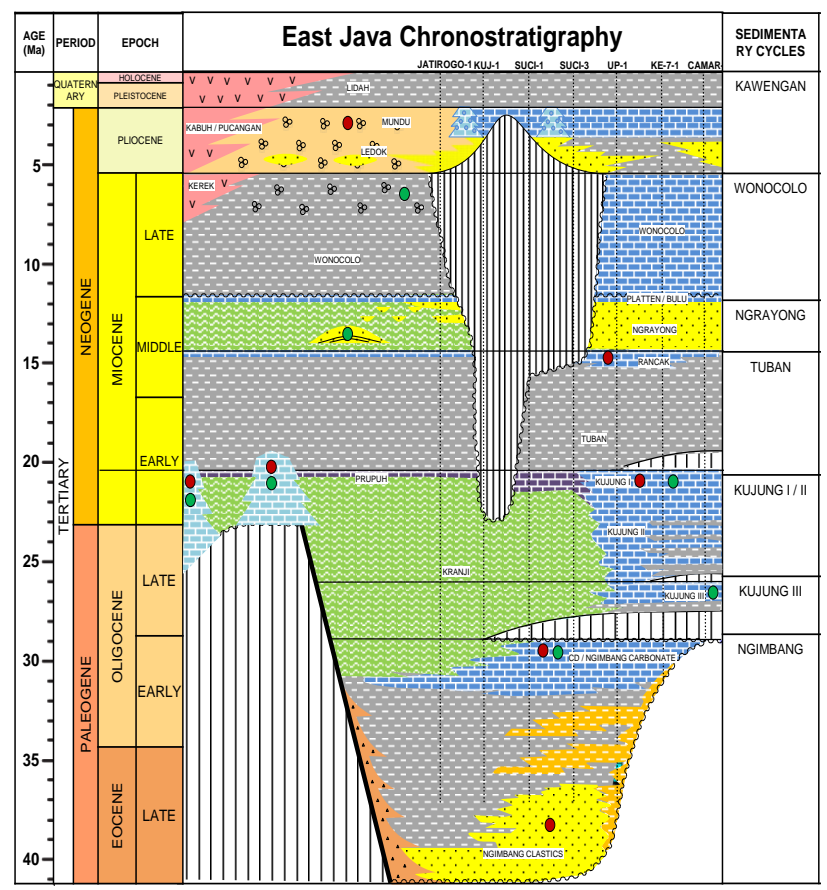

Gambar 1. Stratigrafi Daerah Penelitian. (Saka Indonesia Pangkah Limited, 2012)

\section{TINJAUAN PUSTAKA}

\section{Geologi Regional}

Formasi Ngimbang menandai onset dari sedimentasi tersier pada cekungan Jawa Timur dengan distribusi dari sedimen Formasi Ngimbang bagian bawah dikontrol oleh konfigurasi pra-tersier yang membentuk setengah graben mengarah Timur-Barat. Formasi Ngimbang bagian bawah diperkirakan shallow to marine fluvio-deltaic dan diisi oleh sedimen klastik lacustrine. Formasi ini merupakan sumber hidrokarbon potensial yang penting pada cekungan Jawa Timur yang berdasarkan data geokimia mengindikasikan sumber minyak. Sedimentasi Formasi Ngimbang berlanjut sampai awal Oligosen dengan pengendapan shale, claystone, sedikit karbonat secara transgresi dari Formasi Ngimbang bagian atas.

\section{Impedansi Akustik (AI) dan Impedansi Shear (SI)}

Al atau impedansi akustik atau juga impedansi gelombang $P$ merupakan parameter yang menyatakan sifat kekerasan batuan. Al merupakan parameter yang sensitif terhadap perubahan fluida dalam batuan maupun perubahan lithologi. Secara matematis dirumuskan sebagai :

$$
\mathrm{Al}=\mathrm{Vp} \times \rho
$$

dimana:

Al: Impedansi Akustik (m/s)*(gr/cc)

$\rho:$ densitas ( $\mathrm{gr} / \mathrm{cc})$

$\mathrm{Vp}$ : kecepatan gelombang $\mathrm{P}(\mathrm{m} / \mathrm{s})$

Al lebih dipengaruhi oleh nilai rambat gelombang dibandingkan dengan nilai densitas. Secara umum, Impedansi Shear hampir sama dengan impedansi akustik, perbedaannya pada kecepatan yang digunakan adalah kecepatan gelombang $S$ (Vs). Secara matematis dirumuskan sebagai:

$$
\mathrm{SI}=\mathrm{Vs} \times \rho
$$

dimana:

$$
\begin{aligned}
& \text { SI: impedansishear }(\mathrm{m} / \mathrm{s})^{*}(\mathrm{gr} / \mathrm{cc}) \\
& \rho: \text { densitas }(\mathrm{gr} / \mathrm{cc}) \\
& \text { Vs: kecepatangelombang } \mathrm{S}(\mathrm{m} / \mathrm{s})
\end{aligned}
$$

Karena sifat dari gelombang $S$ yang hanya mengukur rigiditas matriks batuan sehingga keberadaan fluida tidak terdeteksi, gelombang ini hanya akan melewati medium solid, sehingga apabila diolah lebih lanjut, SI dapat merepresentasikan perubahan litologi (Russel \& Hampson, 2006). 


\section{Parameter Vp dan Vs}

Tidak seperti densitas, kecepatan sesimik mengikutsertakan deformasi batuan sebagai fungsi dari waktu. Sebuah kubus batuan dapat mengalami kompresi (compressed), yang mengubah volume dan bentuk batuan, maupun shear (sheared), yang hanya mengubah bentuknya saja.

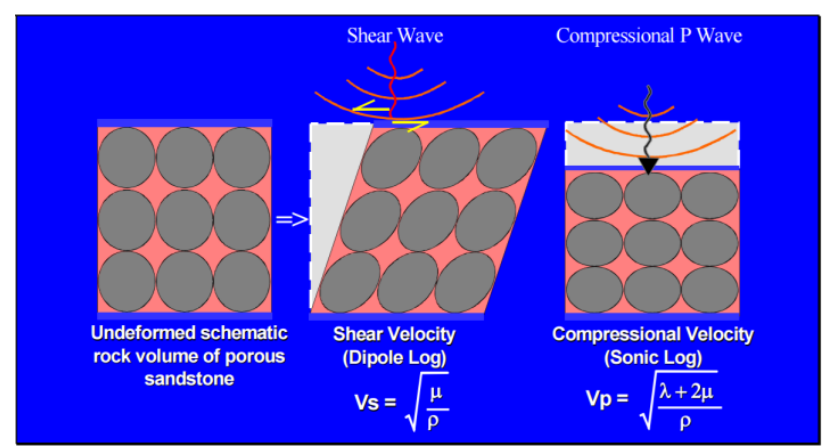

Gambar 2. Deformasi Batuan terhadap Gelombang P dan Gelombang S. (Goodway, 2001)

Dari sini munculah dua jenis kecepatan gelombang seismik yaitu :

a. Kecepatan Gelombang Kompresi (Vp): arah pergerakan partikel sejajar (longitudinal) dengan arah perambatan gelombang.

b. Kecepatan Gelombang Shear (Vs): arah pergerakannya tegak lurus (transversal) dengan arah perambatan gelombang.

Perbandingan antara Vp dan Vs direpresentasikan dengan menggunakan Poisson's ratio $(\sigma)$ sebagai :

$$
\sigma=\frac{\gamma-2}{2 \gamma-2} \quad \gamma=\left(\frac{V_{P}}{V_{S}}\right)^{2}
$$

Bentuk sederhana dari persamaan kecepatan Pwave dan S-wave diturunkan untuk batuan nonporous dan isotropic. Persamaan kecepatan menggunakan modulus Bulk (K), koefisien Lambda $(\lambda)$, dan modulus Shear $(\mu)$ dituliskan sebagai berikut :

$$
\begin{aligned}
& V p=\sqrt{\frac{K+\frac{4}{3} \mu}{\rho}}=\sqrt{\frac{\lambda+2 \mu}{\rho}} \\
& V S=\sqrt{\frac{\mu}{\rho}}
\end{aligned}
$$

dimana :

$\lambda$ : koefisien lambda $=K-2 / 3 \mu$

$K$ : modulus bulk

$\mu$ : modulus

shear

$\rho:$ densitas

\section{Inversi Simultan}

Inversi simultan adalah salah satu metode inversi pre-stack yang menggunakan data angle gather. Inversi ini menggunakan beberapa prinsip dasar (Russel, 2007) antara lain:

1. Linearisasi pada aproksimasi nilai reflekstivitas.

Terdapat hubungan antara nilai impedansi dengan nilai reflektivitas sehingga dapat dibuat model awal (initial model), yakni:

$$
\begin{aligned}
& R_{P i}=\frac{Z_{P i+1}-Z_{P i}}{Z_{P i+1}+Z_{P i}} \approx \frac{\Delta Z_{P i}}{2 Z_{P i}} \\
& R_{P i} \approx \frac{1}{2} \Delta \ln Z_{P i}=\frac{1}{2}\left(\ln Z_{P i+1}-\ln Z_{P i}\right)
\end{aligned}
$$

dimana:

$$
\begin{aligned}
& R_{P i} \text { adalah nilai/koefisien reflektivitas } \\
& \text { gelombang } \mathrm{P} \text { ke-i. } \\
& Z_{P i} \text { adalah impedansi gelombang } \mathrm{P} \text { ke-i. }
\end{aligned}
$$

Dengan In $\mathrm{Zp}=\mathrm{Lp}$, sehingga untuk $\mathrm{N}$ sampel reflektivitas dapat dibuat matriks sebagai berikut:

$$
\left[\begin{array}{c}
R_{P 1} \\
R_{P 2} \\
\vdots \\
R_{P N}
\end{array}\right]=\frac{1}{2}\left[\begin{array}{cccc}
-1 & 1 & 0 & \cdots \\
0 & -1 & 1 & \ddots \\
0 & 0 & -1 & \ddots \\
\vdots & \ddots & \ddots & \ddots
\end{array}\right]\left[\begin{array}{c}
L_{P 1} \\
L_{P 2} \\
\vdots \\
L_{P N}
\end{array}\right]
$$


Atau dapat ditulis juga:

$$
R_{P i}=\left(\frac{1}{2}\right) D L
$$

Lalu dapat dinyatakan hubungan logaritma impedansi dalam seismik trace:

$$
S=\left(\frac{1}{2}\right) W D L_{P}
$$

dimana:

$\mathrm{R}$ adalah vektor reflektivitas,

L merupakan vector logaritma impedasi,

D merupakan matriks turunan,

$S$ adalah seismik trace,

W sebagai matrik swavelet,

$L \mathrm{p}$ adalah vector logaritma impedansi $\mathrm{P}$.

2. Persamaan Aki-Richard.

Dari persamaan dasar Zoeppritz, Aki dan Richards membuat suatu pendekatan yang merupakan lineariasi dari persamaan Zoeppritz yang kompleks dengan memisahkan kecepatan dan densitas. Lalu persamaan tersebut dituliskan kembali menjadi persamaan Fatti, yakni:

$$
R_{p}(\theta)=c_{1} R_{p o}+c_{2} R_{s o}+c_{3} R_{D}
$$

dimana:

$$
\begin{aligned}
& c_{1}=1+\tan ^{2} \theta, \\
& R_{p o}=\frac{1}{2}\left[\frac{\Delta V p}{V p}+\frac{\Delta \rho}{\rho}\right], \\
& c_{2}=-8 \frac{V s^{2}}{V p^{2}} \sin ^{2} \theta, \quad R_{s o}=\frac{1}{2}\left[\frac{\Delta V s}{V s}+\frac{\Delta \rho}{\rho}\right], \\
& c_{3}=2 \frac{V s^{2}}{V p^{2}} \sin ^{2} \theta-\frac{1}{2} \tan ^{2} \theta, R_{D}=\frac{\Delta \rho}{\rho}
\end{aligned}
$$

Lalu digunakan persamaan di atas untuk mendapatkan nilai impedansi gelombang $S$ dan Densitas. Untuk Impedansi S adalah:

$$
R_{S i} \approx \frac{1}{2}\left(L_{S i+1}-L_{S i}\right)
$$

dengan:

In $\mathrm{Zs}=\mathrm{Ls}$, sehingga untuk $\mathrm{N}$ sampel reflektivitas dapat dibuat matriks sebagai berikut:

$$
\left[\begin{array}{c}
R_{S 1} \\
R_{S 2} \\
\vdots \\
R_{S N}
\end{array}\right]=\frac{1}{2}\left[\begin{array}{cccc}
-1 & 1 & 0 & \cdots \\
0 & -1 & 1 & \ddots \\
0 & 0 & -1 & \ddots \\
\vdots & \ddots & \ddots & \ddots
\end{array}\right]\left[\begin{array}{c}
L_{S 1} \\
L_{S 2} \\
\vdots \\
L_{S N}
\end{array}\right]
$$

Atau dapat juga ditulis menjadi:

$$
R_{S}=\left(\frac{1}{2}\right) D L_{S}
$$

Sedangkan untuk Impedansi Dn:

$$
R_{D i} \approx L_{D i+1}-L_{D i}
$$

Dengan $\ln \mathrm{Zd}=\mathrm{Ld}$, sehingga untuk $\mathrm{N}$ sampel reflektivitas dapat dibuat matriks sebagai berikut:

$$
\left[\begin{array}{c}
R_{D 1} \\
R_{D 2} \\
\vdots \\
R_{D N}
\end{array}\right]=\left[\begin{array}{cccc}
-1 & 1 & 0 & \cdots \\
0 & -1 & 1 & \ddots \\
0 & 0 & -1 & \ddots \\
\vdots & \ddots & \ddots & \ddots
\end{array}\right]\left[\begin{array}{c}
L_{D 1} \\
L_{D 2} \\
\vdots \\
L_{D N}
\end{array}\right]
$$

Atau dapat juga ditulis menjadi:

$$
R_{D}=D L_{D}
$$

dimana:

$$
\begin{aligned}
& \text { Rs = vector reflektivitas } \\
& D=\text { matriks derivative } \\
& L=\text { vector logaritma impedansi } \\
& \quad \text { gelombang } S \\
& L d=\text { vector logaritma impedansi densitas } \\
& \text { Ro = vector reflektivitas } \\
& W=\text { matrik swavelet }
\end{aligned}
$$

Lalu ketiga persamaan impedansi terebut digabungkan dalam suatu persamaan Fatti dalam seismik trace menjadi:

$$
S(\theta)=\left(\frac{1}{2}\right) c_{1} W(\theta) D L_{P}+\left(\frac{1}{2}\right) c_{2} W(\theta) D L_{S}+W(\theta) c_{3} D L_{D}
$$


3. Terdapat hubungan linier antara logaritma impedansi $\mathrm{P}$, logaritma impedansi $\mathrm{S}$, dan logaritma impedansi D. Hubungan in idijadikan dasar dari wet trend dan HC trend. Persamaan linier tersebut dapat dituliskan sebagai berikut:

$$
L_{S}=k L_{P}+k_{c}+\Delta L_{S}
$$

dan

$$
L_{D}=m L_{P}+m_{c}+\Delta L_{D}
$$

Sehingga persamaan Fatti berubah menjadi:

$S(\theta)=\left(\frac{c_{1}}{2}\right) W(\theta) D L_{P}+\left(\frac{c_{2}}{2}\right) W(\theta)\left(k D L_{P}+D \Delta L_{S}\right)+W(\theta) c_{3}\left(m D L_{P}+D \Delta L_{D}\right)$

\section{METODOLOGI PENELITIAN}

Pada penelitian ini, data yang digunakan adalah:

a. data sumur sebanyak 2 data (AF2 dan AF3), berupa sumur vertikal, dengan kelengkapan data sumur terdapat pada semua data sumur, kecuali sumur AF3 ysng tidak memiliki data Swave asli;

b. data seismik pre-stack Gather 3D, yang diolah menggunakan fitur AVO pada Hampson Russell untuk mendapatkan Angle Gather.

Penelitian dilakukan dengan terlebih dahulu melakukan precondition data seismik awal berupa PSTM Gather, menjadi data seismik Angle Gather. Kemudian data Angle Gather dibuat ke dalam angle stack, dan dibagi menjadi near angle dan far angle stack. Kemudian dilakukan precondition data sumur, dengan membuat parameter - parameter log yang dibutuhkan, seperti Impedansi $P$, Impedansi $S$ dan rasio Vp/Vs. Proses Well Seismic Tie dilakukan pada data sesimik berupa partial angle stack dengan data sumur AF2 dan AF3. Pembuatan model inisial dilakukan dengan input data yaitu data horizon, data sumur dengan parameter P-wave, S-wave, Density, Impedansi $\mathrm{P}$ dan Impedansi S. Analisa Inversi Simultan dilakukan dengan tujuan menganalisa kelayakan parameter inversi, baru setelah itu dilakukan proses inversi simultan.

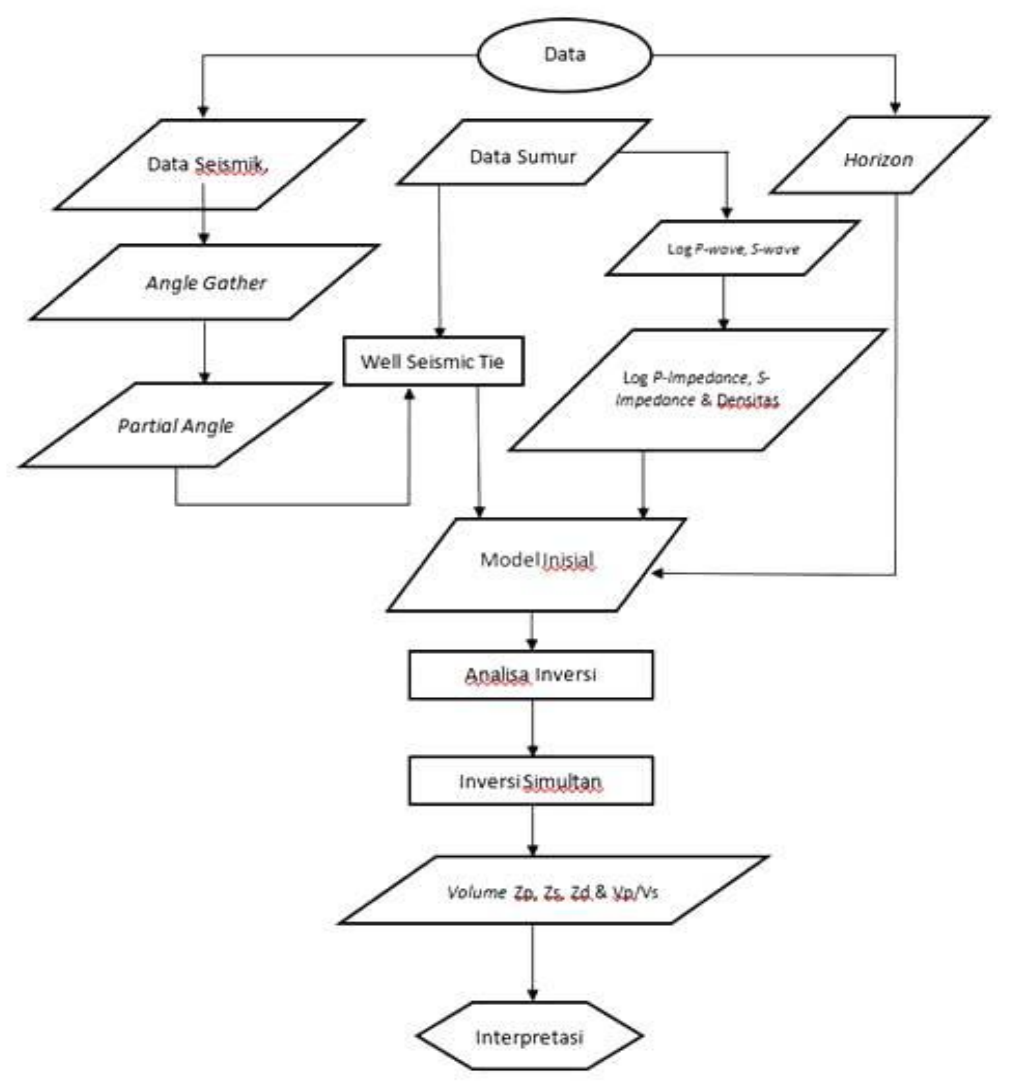

Gambar3. Diagram AlirPenelitian. 


\section{HASIL DAN ANALISA}

\section{Analisa Data Sumur}

Tujuan dilakukan analisa data sumur atau analisa sensitivitas adalah untuk mengetahui parameter yang paling baik untuk digunakan dalam analisa parameter zona target. Pada tiap sumur dilakukan analisa data sumur dengan memanfaatkan log Pwave, S-wave, Densitas, lalu menurunkan log Pwave dan S-wave untuk mendapatkan parameter $\mathrm{P}$ Impedance dan S-Impedance, color key yang digunakan adalah porositas.

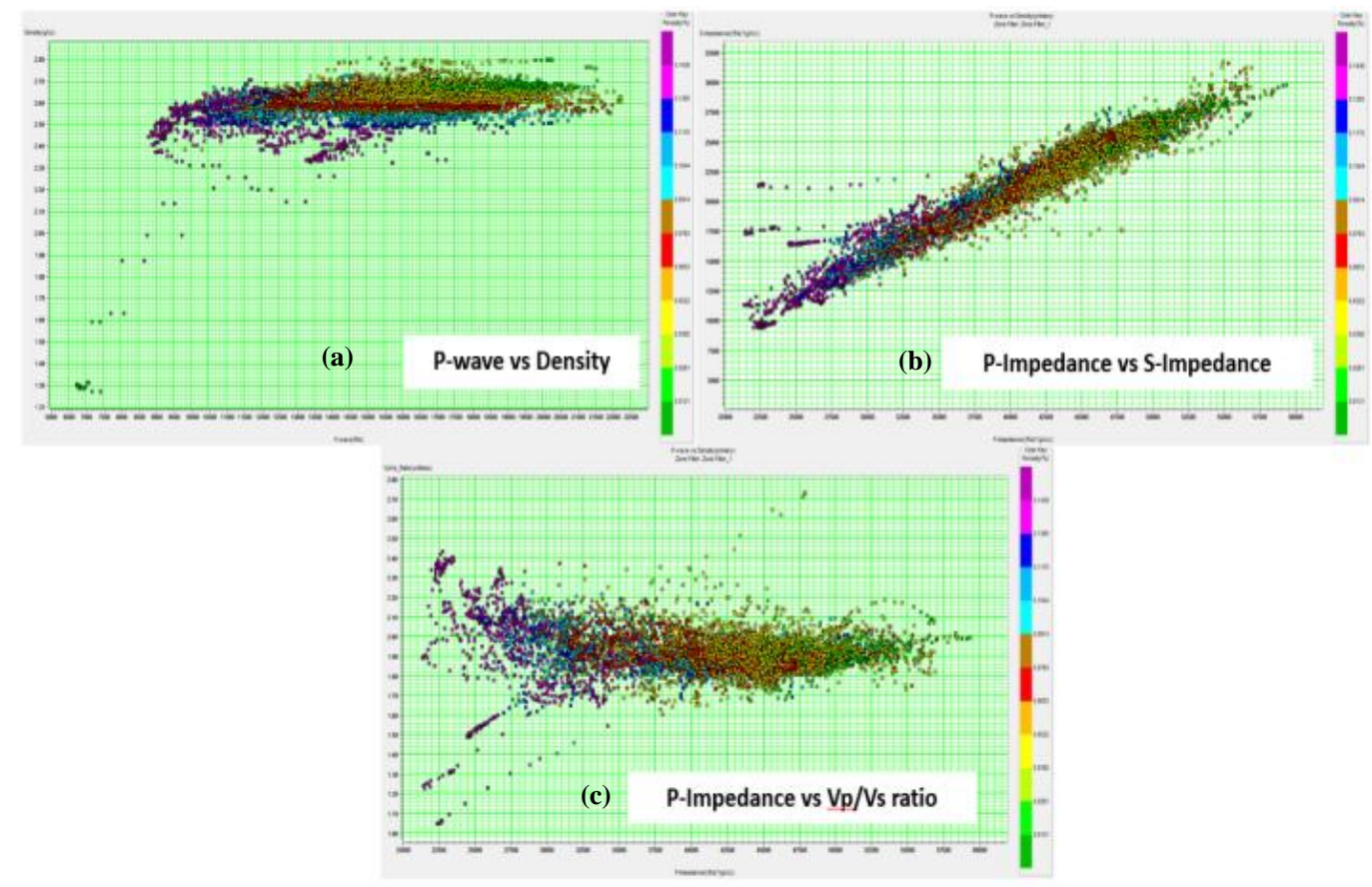

Gambar 4. (a) Crossplot antara P-wave dan Density,

(b) P-Impedance dan S-Impedance,

(c) P-Impedance dan RasioVp/Vs pada Sumur AF.

Berdasarkan analisa sensitivitas pada sumur AF2 di atas, didapatkan bahwa parameter yang paling sensitif untuk menggambarkan kondisi bawah permukaan pada volume inversi adalah PImpedance dan S-Impedance, dilihat dari kemampuannya dalam memisahkan antara karbonat dengan porositas tinggi dan rendah.

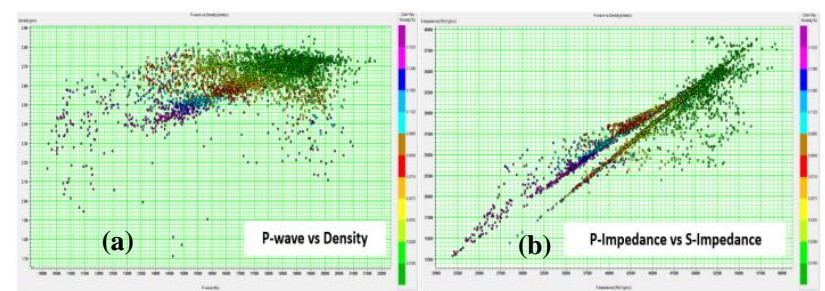

Gambar 5. (a) Crossplot antara P-wave dan Density, (b) P-Impedance dan S-Impedance pada sumur AF3.
Analisa sensitivitas pada sumur AF3 memiliki hasil yang sama, namun pada sumur ini tidak memiliki data S-wave asli, sehingga pada crossplot antara PImpedance dan S-Impedance terdapat dual trend yang membuat interpretasi pada sumur AF3 dilakukan hanya pada volume P-Impedance.

\section{Analisa Well Seismic Tie}

Proses pengikatan data sumur dengan data seismik dilakukan pada data seismik berupa partial angle stack, dimana terbagi ke dalam dua angle yaitu near angle dan far angle stack. Korelasi antara data sintetik seismogram dengan data seismik asli akan semakin baik apabila terdapat kecocokan fasa dari keduanya, serta frekuensi. Oleh karena itu, pada penelitian ini, dilakukan rotasi fasa pada data 
seismik yaitu sebesar 37 derajat, kemudian dilakukan proses Well Seismic Tie dengan menggunakan wavelet Ricker sebesar $15 \mathrm{~Hz}$, pada Formasi Ngimbang.

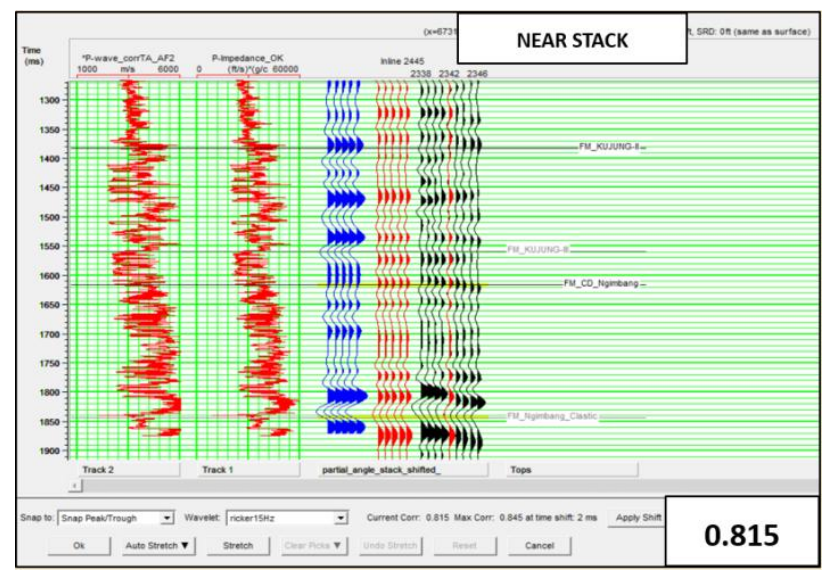

(a)

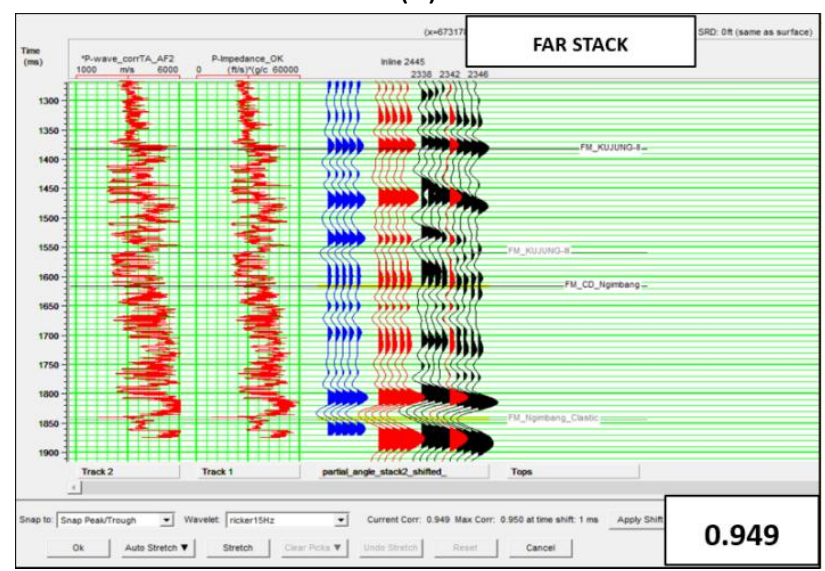

(b)

Gambar 5. (a) Well Seismic Tie untuk Near Stack dan (b) Far Stack pada Sumur AF2.

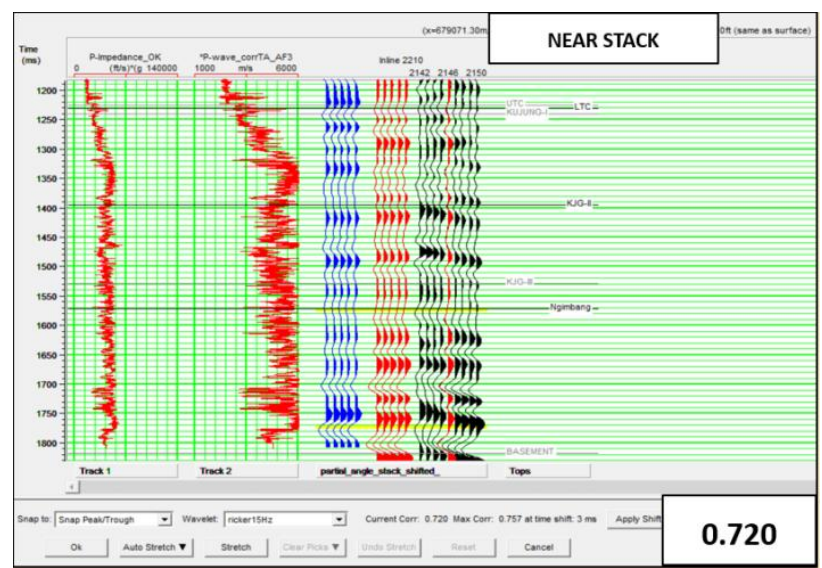

(a)

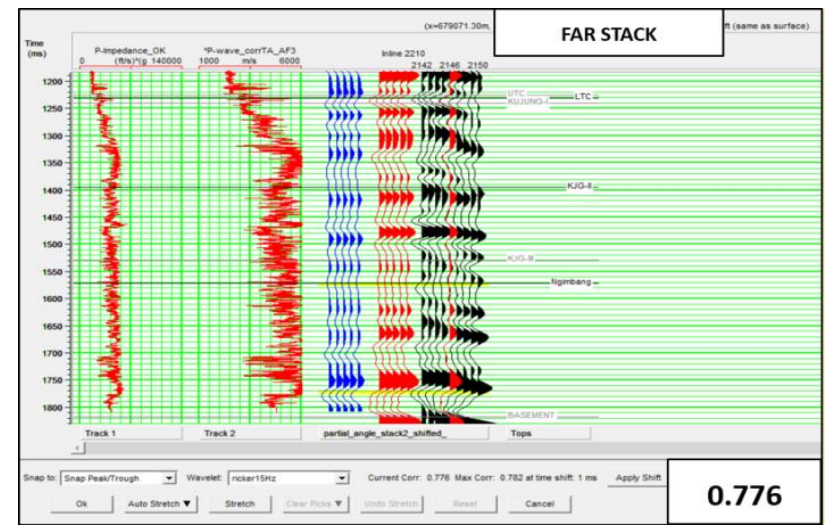

(b)

Gambar 6. (a) Well Seismic Tie untuk Near Stack dan (b) Far Stack pada Sumur AF3.

\section{Analisa Inversi Simultan}

Inversi Simultan dilakukan dengan membuat model inisial, yang dibuat dengan input dari data seismik berupa angle gather, data horizon, serta data sumur dengan parameter berupa $\mathrm{P}$-wave, $\mathrm{S}$ wave, Densitas, Impedansi P dan Impedansi S. Hasil model yang didapatkan berupa model Impedansi $P$, Impedansi $S$ dan Densitas untuk tiap - tiap sumur. Pada penelitian ini, dilakukan pembuatan model dengan horizon CD Ngimbang dan Ngimbang Clastic hingga proses inversi. Berikut merupakan contoh model untuk Impedansi P pada sumur AF2.

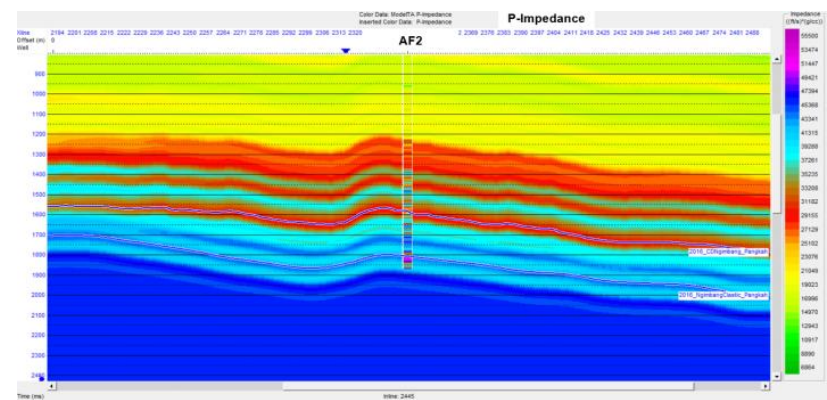

Gambar 7. Model Impedansi P untuk Sumur AF2.

Selanjutnya, proses inversi dilakukan dengan range data di sekitar dua sumur yaitu AF2 dan AF3, sesuai dengan hasil pada analisa sensitivitas bahwa parameter yang akan digunakan dalam inversi simultan adalah P-Impedance dan S-Impedance, dan untuk sumur AF3, hanya pada P-Impedance. Pada penelitian ini, inversi dilakukan dengan range time 
window antara 1500 sampai 2500 ms, dengan fokus terhadap formasi Ngimbang.

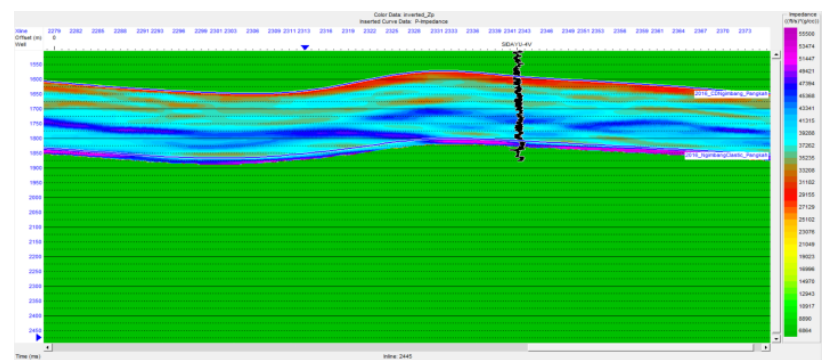

(a)

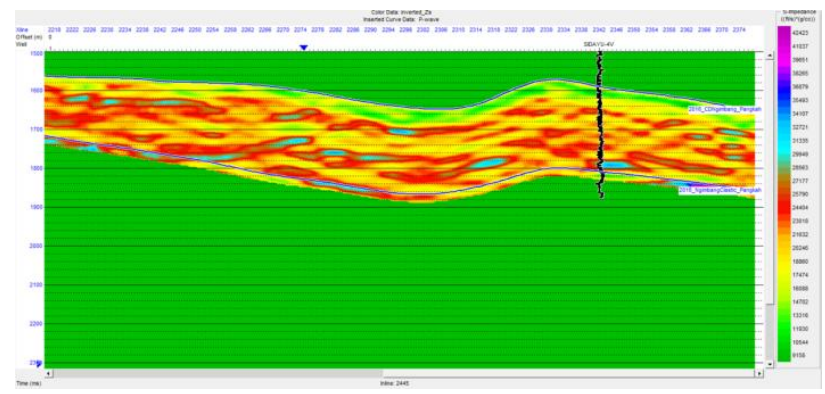

(b)

Gambar 8. (a) Hasil Inversi Parameter P-Impedance dan (b) S-Impedance pada Sumur AF2.

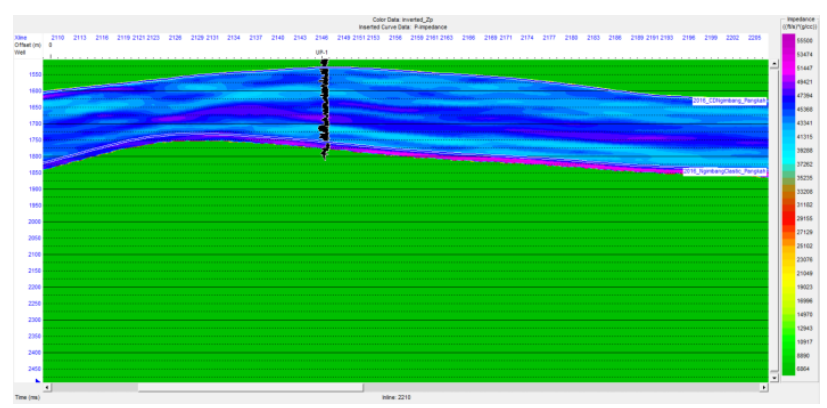

Gambar 9. Hasil Inversi parameter P-Impedance pada Sumur AF3.P

\section{Interpretasi}

Interpretasi dilakukan pada penampang PImpedance dan S-Impedance untuk sumur AF2, dan P-Impedance untuk sumur AF3. Pada sumur AF3, hasil inversi simultan menunjukkan bahwa tidak ditemukan adanya anomali impedansi rendah, terlihat dengan nilai impedansi yang relatif tinggi pada sumur tersebut, antara 40543 - 48976 $(\mathrm{ft} / \mathrm{s})^{*}(\mathrm{gr} / \mathrm{cc})$. Untuk memastikan apakah terdapat zona target pada sumur AF3, dilakukan crossplot dengan memanfaatkan saturasi air dan porositas, untuk melihat kandungan fluida pada daerah target.

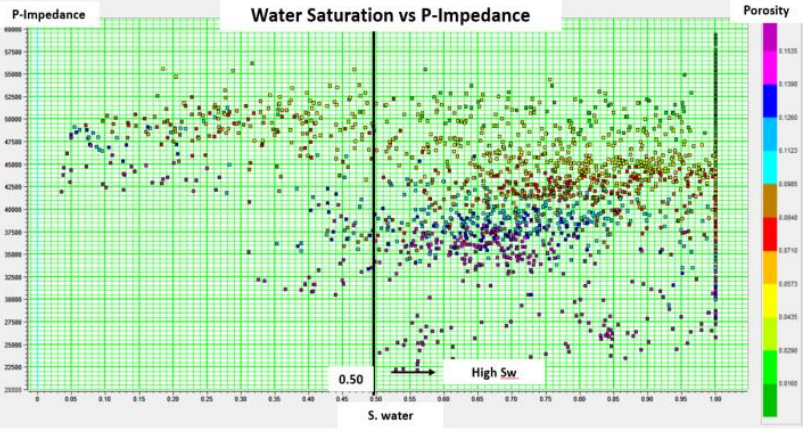

Gambar 10. Crossplot Saturasi Air dengan P-Impedance pada Sumur AF3.

Berdasarkan analisa kandungan fluida pada Gambar 10, didapatkan bahwa nilai saturasi air tinggi ( $>0.5$ ) berada pada porositas yang relatif tinggi ( $>10 \%$ ), hal ini menunjukkan bahwa besar kemungkinan pada sumur AF3 tidak ditemukan adanya zona hidrokarbon, didukung pula dengan hasil inversi dari penampang P-Impedance, sehingga diambil kesimpulan bahwa pada sumur AF3 untuk formasi Ngimbang tidak ditemukan zona target.

Selanjutnya pada sumur AF2, zona target didapatkan dengan melihat nilai impedansi rendah, pada P-Impedance dengan kisaran nilai antara 33208 - $43341(\mathrm{ft} / \mathrm{s})^{*}(\mathrm{gr} / \mathrm{cc})$, dan S-Impedance antara 16088 - $25790(\mathrm{ft} / \mathrm{s})^{*}(\mathrm{gr} / \mathrm{cc})$. Selanjutnya dibuat slicing map dengan memotong pada bagian reservoar level, untuk melihat persebaran dari zona target. Peta slicing dibuat pada masing - masing parameter P-Impedance dan S-Impedance.

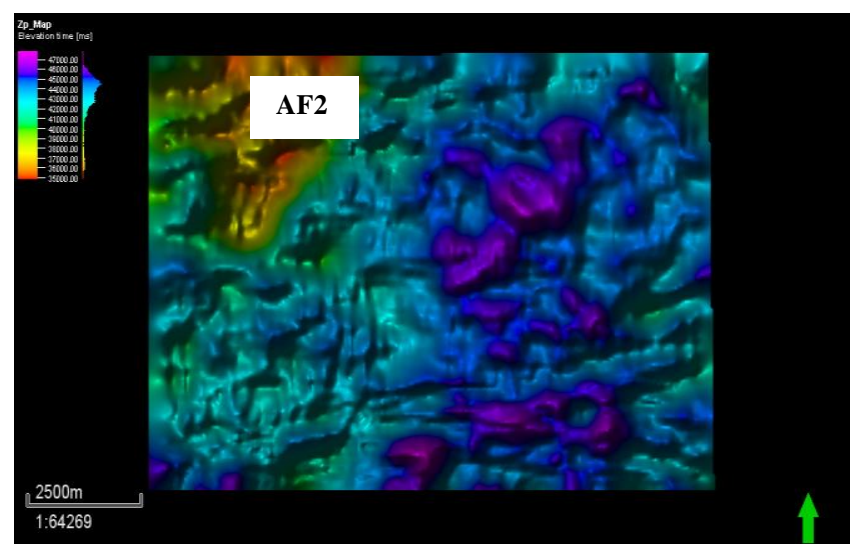

Gambar 11. Slice Map pada Penampang P-Impedance. 


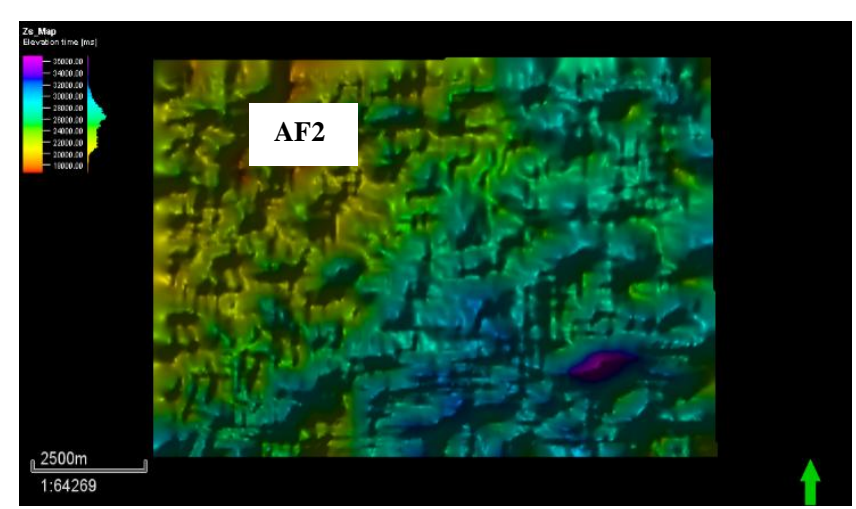

Gambar 11. Slice Map pada Penampang S-Impedance.

Selanjutnya, untuk mendapatkan persebaran yang lebih baik dari peta P-Impedance dan SImpedance, dilakukan perkalian antara keduanya, tujuannya adalah untuk mendapatkan nilai kontras impedansi yang lebih besar antara impedansi tinggi dan impedansi rendah, dengan demikian, akan didapatkan persebaran yang lebih baik.

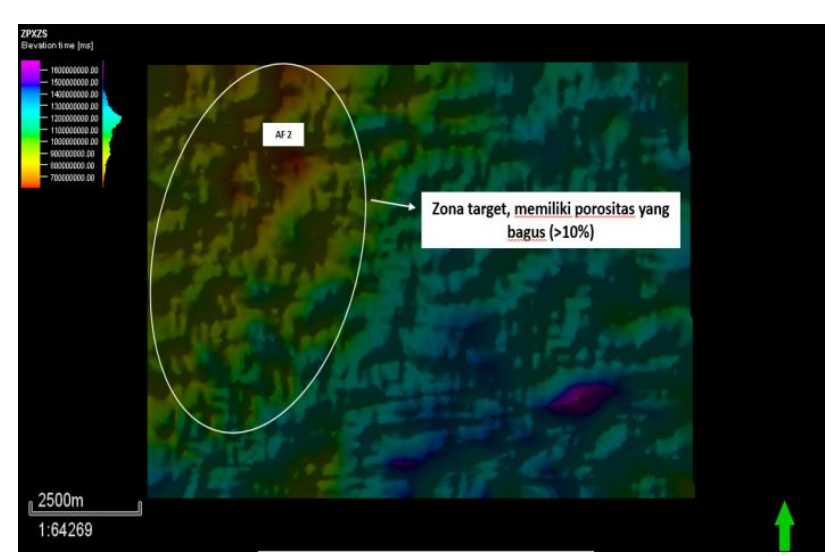

Gambar 12. Slice Map Perkalian antara P-Impedance dan S-Impedance.

Berdasarkan Gambar 12 di atas, didapatkan persebaran yang lebih teliti dengan melakukan perkalian antara peta P-Impedance dan SImpedance, zona target diketahui memiliki nilai porositas yang baik, yaitu di atas $10 \%$. Perlu dicatat bahwa tujuan penelitian ini adalah untuk melihat persebaran dari zona target, yang dianggap merupakan reservoar karbonat pada formasi Ngimbang, sehingga untuk hal terkait kandungan fluida, hingga lingkungan pengendapannya, diperlukan analisa lebih lanjut. Berdasarkan Gambar
12, zona target memiliki persebaran relatif berada pada arah Barat Laut dari sumur AF2.

\section{PENUTUP \\ Kesimpulan}

Kesimpulan yang didapat dari penelitian ini antara lain.

1. Pada sumur AF3 tidak didapatkan zona yang terindikasi hidrokarbon berdasarkan hasil inversi dan didukung dengan analisa fluida menggunakan informasi saturasi air, dimana pada porositas tinggi, memiliki saturasi air tinggi $(>0.5)$

2. Pada sumur Af2 Inversi Simultan dapat menentukan parameter zona yang diduga sebagai reservoar karbonat pada daerah penelitian, dengan nilai $\mathrm{P}$-Impedance antara 33208 - $43341(\mathrm{ft} / \mathrm{s})^{*}(\mathrm{gr} / \mathrm{cc})$ dan nilai SImpedance antara $16088-25790(\mathrm{ft} / \mathrm{s})^{*}(\mathrm{gr} / \mathrm{cc})$, dimana zona prospek tersebut memiliki porositas yang baik (> 10\%).

\section{Saran}

Saran yang dapat diberikan berdasarkan hasil dan kesimpulan untuk membangun hipotesahipotesa selanjutnya antara lain.

1. Diperlukan sumur tambahan dengan informasi gelombang $\mathrm{S}$ asli, agar interpretasi dapat dilakukan dengan lebih baik.

2. Perlu dilakukan analisa geologi untuk interpretasi yang lebih valid.

3. Perlu dilakukan analisa inversi dengan membuat parameter yang lebih sensitif untuk menganalisa fluida seperti lambda-mu rho (LMR) dan Elastic Impedance (EI).

\section{Ucapan Terima Kasih}

Penulis mengucapkan terima kasih kepada dosen-dosen pembimbing IbuWien Lestari dan Bapak Firman Syaifuddin, sertakepada Pak Farid Dasa Marianto, selaku mentor penulis di perusahaan tempat penulis melakukan penelitian, atas ide penulisan dan pengarahannya selama proses penelitian hingga penulisan. 


\section{DAFTAR PUSTAKA}

Friadi Sinaga, Jan., 2011. Pemetaan Litologi Batupasir pada Lapangan " $X$ " Cekungan Sumatera Selatan dengan Seismik Inversi Simultan. Skripsi. Institut Teknologi Bandung. Bandung.

Goodway, B., 2001. AVO and Lamé Constants for Rock Parameterization and Fluid Detection. Calgary: PanCanadian Petroleum Limited.

Razi, Muhammad., 2007. Aplikasi Metoda Seismik Inversi Simultan untuk Mengetahui Penyebaran Reservoir Batupasir - A3 pada Lapangan " $X$ " Cekungan Sumatera Selatan. Skripsi. Institut Teknologi Bandung. Bandung.

Russel, B., 2007. The Old and The New in Seismic Inversion". The 2006 - 2007 Canadian Society of Exploration Geophysicist (CSEG) Distinguished Lecture. Calgary.

Russel, B., Hampson, D., 2006. AVO Theory" Software Hampson Russell. Calgary.

Russel, B., Hampson, D., 2006. Strata Theory. Software Hampson Russell. Calgary.

Saka Energi Indonesia., (2012). Well Report. 